\title{
Will Biodiversity Be Conserved in Locally-Managed Forests?
}

\author{
Jeffrey Sayer ${ }^{1, *}$, Chris Margules ${ }^{1,2}$ and Agni Klintuni Boedhihartono ${ }^{1}$ \\ 1 Center for Tropical Environmental and Sustainability Science, James Cook University, Cairns, QLD 4870, \\ Australia; chrismargules@gmail.com (C.M.); agni.boedhihartono@jcu.edu.au (A.K.B.) \\ 2 Research Center for Climate Change, University of Indonesia, Kota Depok, Java Barat 16424, Indonesia \\ * Correspondence: jeffrey.sayer@jcu.edu.au
}

Academic Editor: Andrew Millington

Received: 16 November 2016; Accepted: 9 January 2017; Published: 13 January 2017

\begin{abstract}
Recent decades have seen a rapid movement towards decentralising forest rights and tenure to local communities and indigenous groups in both developing and developed nations. Attribution of local and community rights to forests appears to be gathering increasing momentum in many tropical developing countries. Greater local control of forest resources is a response to the failure of government agencies to exercise adequate stewardship over forests and to ensure that the values of all stakeholders are adequately protected. We reviewed evidence of the impact of decentralised forest management on the biodiversity values of forests and conclude that special measures are needed to protect these values. There are trade-offs between shorter-term local needs for forest lands and products and longer-term global needs for biodiversity and other environmental values. We present evidence of local forest management leading to declining forest integrity with negative impacts on both local forest users and the global environment. We advocate greater attention to measures to ensure protection of biodiversity in locally-managed forests.
\end{abstract}

Keywords: community forest management; decentralised forest management; forest biodiversity conservation; indigenous forest management

\section{Introduction}

Deforestation has been a focus of environmental concern for several decades. Recently the rate of deforestation has slowed and in many countries forests are expanding again. Only a small number of less-developed tropical countries continue to lose forests [1,2]. Forest decline does continue in very important tropical forest countries, such as Brazil and Indonesia. The areas still being lost are often of high biodiversity value. [3]. Areas of natural or primary forests-those with minimal human modification-continue to decrease [4]. We argue that the problem is shifting from loss of forest extent to loss of forest quality and ecological integrity [1]. The move to decentralised management is amplifying risks of significant decline in forest quality, particularly, for loss of forest biodiversity.

Just as we are within sight of solving the problem of deforestation by reversing forest decline other major challenges to forest conservation are emerging. Forests are increasingly fragmented and subject to unsustainable harvesting of numerous products. Invasive species are a major threat to forests worldwide. Climate change is placing stress on forest systems in novel ways. The papers in this Special Issue of "Land" [5] are intended to draw attention to some of the special problems posed by the decentralisation of forest management for biodiversity. We contend that decentralization of management is shifting the balance of concern for forests away from their global public goods values towards more local instrumental values. Local communities are inevitably going to be more concerned about the immediate values that they can derive from forest lands and less concerned with values such as carbon retention, biodiversity conservation, and larger scale hydrological functions [6]. 
Communities and indigenous peoples are asserting their rights to recover control of forests that they have exploited sustainably often for many generations [7]. Over 50\% of protected areas have been established on lands that indigenous peoples have traditionally occupied and used [8]. In many parts of the world local and indigenous peoples are challenging the legitimacy of protected areas which they perceive to be "land grabs" by conservationists $[9,10]$. There are many situations where local peoples have a strong conservation ethic and are powerful advocates for biodiversity conservation [11], but there is surprisingly little empirical evidence for the extent and effectiveness of decentralized management in achieving biodiversity conservation goals. Local people asserting their rights to self-determination consider that their short-term needs to clear forests for agriculture or to hunt and log in forest areas have greater legitimacy than externally-imposed conservation goals. Advocates of local forest management often claim that local communities will conserve biodiversity more effectively than governments but they rarely present empirical evidence to support these claims. Decentralisation of forest management is advancing rapidly in the absence of real evidence that it is effective in conserving biodiversity. Despite the obvious risk in this course of action many are arguing for even greater allocation of forests to indigenous and local peoples $[12,13]$.

Local self-determination and access to local natural resources is a basic human right but it is always necessary to balance local interests with national, regional or even global interests. The perennial dilemma of conserving the public goods values of forests whilst meeting the immediate needs of local residents has been a central theme in forest stewardship throughout history $[14,15]$. The tension between local self-determination and the conservation of public goods has been a dominant issue in the development of forest conservation strategies in recent years [16]). The changing thinking on conservation is summarised in the following statement from the activist non-governmental organisation, the Forest People's Programme.

In recent years, agreements have been made in several international processes clearly implying that conservation initiatives must respect indigenous peoples' rights. Well-known examples are the Durban Accord and Durban Action Plan (World Parks Congress 2003); the resolutions and recommendations of the World Conservation Congresses of the IUCN, and the Programme of Work on Protected Areas of the CBD and other CBD COP Decisions. This new attitude towards conservation is sometimes called the 'new paradigm on conservation' [17].

Local communities, indigenous peoples, and the conventional conservation community are in conflict over who should best control forest conservation programmes. The International Union for Conservation of Nature has established the Whakatane Mechanism in an attempt to mediate this debate.

The aim of the Whakatane Mechanism is to assess the situation in different protected areas around the world and, where people are negatively affected, to propose solutions and implement them. It also celebrates and supports successful partnerships between peoples and protected areas [8].

The tension over local control does not only apply to protected areas. Many countries designate most of their forests as "permanent forest estate" where strictly-regulated offtakes of timber and non-timber products is allowed, or where hunting is regulated. Local people are claiming rights to these forests and are particularly vigorous in asserting these rights in situations where state forest agencies are complicit in corporate land grabs. There are numerous examples of industrial forests and estate crops impacting negatively on local livelihoods. Communities are justifiably organising themselves to defend these forests against industrial take over. Communities argue that if they are given secure forest tenure they will be empowered to resist industrial land grabs.

Rural populations, especially in the tropics are increasingly connected to the broader economic landscape. Populations are growing rapidly and naturally aspire to greater material well-being. Rural and forest-dwelling peoples are becoming more assertive in defending their rights to the land [11,12]. Powerful advocacy groups have emerged to defend indigenous and local forest rights. 
One of the most effective has been the Rights and Resources Institute (RRI) located in Washington DC (http:/ / rightsandresources.org/). A recent study by RRI in collaboration with the World Resources Institute (WRI) and the Woods Hole Research Center [18]) argues that the expansion of local indigenous land rights would be the most cost-effective way of protecting forests, sequestering carbon, and mitigating climate change. Civil society groups are organising to champion indigenous peoples' forest rights in many countries. In Indonesia the non-governmental organisation Aliansi Masyarakat Adat Nusantara (AMAN http://www.aman.or.id/) has lobbied successfully for political support and legal changes to allow local people to claim ownership of forests that were previously state forest land or protected areas.

Demands for more local control of forests appear to be, at least in part, a reaction to a recent historical period when governments have focused almost exclusively on industrial timber harvesting and conversion of forests to agriculture. In many tropical countries governmental laws and forest agencies have paid little attention to the importance of forests in the livelihoods of local people. Historically there has been an ebbing and flowing of the degree to which control of forests is centralised [19].

Traditional "adat" communities in Indonesia, for example, now claim ownership of a major part of the country's forests (http://www.aman.or.id/). In Indonesia, and many other countries, it is claimed that local control of forests, particularly by indigenous peoples, will provide the best mechanism for conserving all forest values. However many observers have noted that decentralisation of management is difficult to achieve in an equitable manner [19-21]. Governments are reluctant to relinquish control of forests, or they do so whilst leaving in place restrictions that hinder local people in obtaining benefits from the forests $[22,23]$. The difficulties of ensuring equitable governance of any forests, and especially those under local management, are well documented [24,25]. It takes time to put in place the correct mix of regulations and governance structures to ensure that local forest management is sustainable [26]. The appropriate mix of rules and structures will change over time as the development context of the country evolves. In many instances in recent years the rush to empower local communities and to decentralize forest management has led to the allocation of rights to communities without measures to ensure that these communities are held responsible for sustaining all forest values [6]. Community forests have been badly managed in some countries [27] and there are anecdotal accounts of communities selling their forest rights to oil palm companies in Indonesia and to large scale agricultural enterprises in the Amazon.

Studies of the extent to which local control increases or reduces deforestation have shown that the situation is very variable and dependent on local contexts [28]. The papers in this special issue on "Biodiversity in Community-Managed Forests" explore some of the issues and tensions that occur where local communities are given responsibility for those forests that have global biodiversity values.

Local control could facilitate the use of climate change mitigation funds (REDD+) to reduce deforestation [29]. Progress in implementing REDD+ schemes has been slow and potential impacts of REDD+ on biodiversity have received little attention. Aid agencies and international non-governmental organisations have been promoting community forest management as a means to enable communities to benefit from REDD+ funds. Aid agencies appear to have assumed that communities would conserve global forest values such as biodiversity $[21,26]$. We contend that there is little evidence to support the assumption that local forest stewardship will automatically ensure the maintenance of the public goods values of forests. There are unresolved assumptions about what defines communities and cultures [30]:

"Community-based natural resource management discourses produce images of cultures, communities; and resource management practices that are essentialized, timeless, and homogeneous? In their role as advocates of local resource management regimes, NGOs acting on behalf of local communities may, in part, be constituting the entities whose interests they claim to represent. To what extent might such instances of the "invention of community" have positive or problematic consequences? To what extent, and how, do these representations reflect local concerns, NGO preoccupations, or the interests of transnational conservation, human rights, and environmental 
donors? How have descriptions of local communities, culture, law, and environmental management been creatively shaped to fit larger institutional interests?" [30]

\section{What Is the Evidence for Biodiversity Gains from Local Management?}

There are surprisingly few studies of the effectiveness of local forest management in conserving biodiversity. Kellert et al. [21] concluded that the record is mixed, and in most of the situations they examined community management had been relatively unsuccessful in either delivering local benefits or conserving biodiversity. Brosius et al. [30] raised the concern that the proliferation of movements and agendas on community, territory, conservation, and the indigenous paradigm means that donor institutions and government agencies need to be more careful in making decisions and giving support to different groups. Many international and local organizations have been involved in the setting up of community-based natural resources management programs (CBNRM) in different parts of the world. The success of these programs has been the subject of controversy. The interpretation of the impacts of CBNRM depends upon the perspective of the observer. Conservation institutions, development organizations, and indigenous people's representatives have differing perspectives on what constitutes success. Studies in Nepal have shown that biodiversity conservation has not received much attention in community managed forests and biodiversity has declined or been altered in these forests $[31,32]$. There are numerous studies of the effectiveness of local management in delivering economic benefits to local communities, but statements about the broader environmental benefits of local management appear mostly to be aspirational. Local management is largely promoted by development practitioners and non-governmental organisations supporting local and indigenous peoples' interests. This community of practitioners does not have specific expertise or interest in biological diversity and appears often to equate maintenance of tree cover with biodiversity conservation.

Conservation biologists do not appear to have engaged significantly with local management advocates - they choose to work mainly in locations that are uninhabited or are within protected areas. Conservation biologists have the skills and competencies to measure the effectiveness of local management in conserving biodiversity but with a few exceptions they have not addressed this issue $[15,21,28]$. One notable exception is that conservation biologists have engaged strongly with local communities in areas of known high biodiversity value, and particularly around protected areas. There is a long and mixed history of attempts to promote local development around protected areas in order to reduce pressures on those areas [33]. The recent interest in conservation landscapes provides another example of constructive interactions between conservation biologists and local communities [34]. Conservation landscapes are now included in international lists of protected areas maintained by the International Union for Conservation of Nature, but as the paper by Dudley et al [34]. in this volume shows, there is no systematic effort to assess their biodiversity benefits.

Sustainable wildlife harvesting for food and for sport is well documented and its impacts on biodiversity well known, but controversial. Wild animal populations can sometimes sustain quite heavy levels of harvesting [35], but certain species are much more susceptible than others, and may rapidly decline to extinction [36]. Reductions in populations of larger birds and mammals that have important roles in seed dispersal in forests can lead to rapid declines in tree species diversity and to great reductions in overall forest biodiversity (Terborgh and Perez this volume; [37]). Biodiversity conservation, in many countries, has benefitted from measures taken to improve wildlife habitats for sport hunting, although such measures may not benefit the full range of native biodiversity-predators, for instance, may be eliminated to favour the quarry species sought by hunters.

Initiatives in more developed countries often do benefit biodiversity in locally-managed forest areas. In situations with well-educated and prosperous people, citizen science emerges and people often self-organise to support biodiversity conservation efforts-often in areas under local management [38,39]. Consortia of conservation organisations, governments, and industry can collaborate to conserve biodiversity in areas under local management [40]. 
The emerging trend towards integrated landscape approaches to balancing conservation and development shows considerable promise for enabling conservation to occur in complex landscapes that include locally-managed areas [41]. However even though landscape approaches are widely used by organisations that have biodiversity conservation as a major part of their mandate there is, as yet, little empirical evidence for their effectiveness in conserving biodiversity [42].

One review of the literature on biodiversity in forests placed under local control [43] concluded that numerous studies showed short-term biodiversity losses. The study concluded that significant areas needed to be closed to any use, but also argued that, in many situations, local management offered better prospects for long-term sustainability of conservation efforts [43].

Several authors have pointed out that the naive perception of community as a homogeneous group having a common vision of conservation is incorrect [20]. Studies have emphasized that "there is need for a critical perspective of "who actually conserves" in various conservation activities. Community-based conservation programmes should recognise the internal differentiation within the communities" [44]. Inevitably there is an inequitable distribution of rights and responsibilities for natural resource management in any community. Community-based conservation may be here to stay. The question is how a community's involvement can be made effective. Protection of biodiversity must be based on a wide range of approaches to develop a shared understanding of compatible conservation and development goals at various levels [44].

\section{Conclusions}

Local management is not a panacea and its success or failure is highly context specific. Numerous studies have highlighted the conditions under which community management tends to be successful [26,45], but they almost all focus on local livelihood benefits and do not explicitly address global public goods values, such as biodiversity. The present expansion of initiatives to devolve forest management to local and indigenous communities clearly requires that more effort is made to assess the impact of local management on biodiversity values. Experience in richer countries suggests that biodiversity values can be maintained in areas under local management when those local managers are motivated to do so or when strict conservation laws are imposed. In poor countries where people are struggling to survive it would be unwise to assume that global environmental values will be a priority. Biodiversity conservation will take second place to immediate development needs in these poorer countries. One could argue that biodiversity should not be a priority in situations where local people are living in poverty. However, the long-term sustainability of local peoples' forests will be in jeopardy if the biodiversity of the forests declines. It will be necessary to have significant areas excluded from human use if biodiversity is to persist. If the allocation of land to these protected areas impacts negatively on local livelihoods, then the global community should compensate local people for the costs they incur. The moral requirement to make such payments for ecosystem services is manifest, but there has been remarkably little progress in putting into place payment schemes for measures to conserve biodiversity [46]. The alternative is to impose strict rules to protect biodiversity in those areas placed under local management. The rush to devolve management is occurring without sufficient attention being given to the need for such special conservation measures. There is a dangerous assumption that local people will protect wild species and will not pose a risk to biodiversity but this has repeatedly been shown to be untrue [3,47] (Terborgh, this volume). Achieving the correct balance between collective rights and individual rights is important when rights to natural resources are allocated. Brosius et al. [30] emphasize that the tension between collective rights and individual rights should receive more attention in moves towards political decentralization and local autonomy. They question "What are the consequences of recognizing community autonomy for larger visions of pluralist civil society? When "natives" become privileged, are other social groups marginalized? What space is there for mobility, migration, and the movements of both rural and urban poor?" [30].

A meta-study of 101 conservation initiatives in territories of indigenous people from 2002 to 2012 assessed whether these conservation initiatives benefitted people and whether collaboration 
between indigenous groups and outside agencies improved indigenous economies and protected the environment [47]. The study showed that many communities have suffered displacement and increased poverty as a result of losing lands and resources to conservation authorities.

We contend that the move towards greater degrees of local management is, in general, a good thing. However, until such a time as people have met their material needs and have the education and leisure to value biodiversity, they will not conserve the full range of wild species. We propose the following nine measures that would help to ensure that biodiversity goals are met when forest management is decentralised, the measures reflect those that have been advocated for the management of common property resources $[48,49]$ and others that have been identified as preconditions for the success of integrated landscape approaches to conservation and development [39].

- Clear rules defining both rights and responsibilities must be in place. The reality that there will always be a divergence of views amongst different stakeholders must be recognised and addressed.

- Public goods values have to be identified and clarified. The broader environmental objectives for locally-managed areas must be made explicit and measures must be put in place to ensure that these values are maintained.

- A neutral forum for resolving conflicts and reconciling trade-offs between local and public benefits must be established. A process must be in place to enable advocates for local benefits to engage in dialogue with advocates for broader biodiversity and other environmental values.

- Effective compensation mechanisms must be in place to pay local people for the opportunity costs they incur when biodiversity measures conflict with the local use of forests.

- Contributions of locally-managed forests to broader landscape values must be made explicit. Landscape approaches provide a tool for optimising biodiversity benefits of locally-managed areas by understanding the role of these areas in the broader landscape. Locally-managed areas may act as buffers around protected areas or may provide corridors linking natural areas. Locally-managed areas may provide better biodiversity benefits if they are located adjacent to refuge areas [38,41].

- Assessment, monitoring, and adaptive management must be implemented. Local management must provide for assessment of biodiversity values and for monitoring and understanding changes in biodiversity. Measures must be in place to allow for management to be adapted to meet specific needs of biodiversity conservation.

- Legally-mandated institutions must be in place to oversee local management and to ensure that the public goods values of locally-managed forests are protected.

- Special attention must be given to the interests of people practicing traditional lifestyles and belief systems as their needs and potential will differ from those of people who are already part of the cash economy.

The move to local management and the emergence of the "new paradigm for conservation" can provide a basis for better conservation of forest resources including biodiversity $[40,50])$. However, as the studies in this volume show, the present movement to hand over forest management to communities when checks and balances are not in place to ensure protection of public goods values, such as biodiversity, is dangerous (Terborgh and Peres, this volume; Langston et al. [51]) and runs the risk of serious depletion of the world's biodiversity, especially the numerous unique species of tropical forests. The loss of some of these species may lead to a decline in ecosystem functions and a progressive degradation of the forest and its broader values, including the values that local people obtain from the forests. The principles outlined above must be rapidly applied in tropical developing countries that are at the forefront of the move to decentralised management. 
Acknowledgments: We thank the numerous local communities with whom we have worked and whose experience with local forest management has inspired this study. Staff of the Samdhana Institute and Birdlife Indonesia, World Wildlife fund Indonesia and in the Congo Basin and Conservation International in Indonesia for discussions and access to field sites that enriched our understanding of decentralised forest management. We thank Chip Fay, Marcus Colchester, Jatna Supriatna, Nonette Royo, Dominique Endamana and Leonard Usongo for valuable discussions of community and indigenous management.

Author Contributions: The authors reviewed the literature and contributed their personal experience of biodiversity outcomes in forests managed by local communities in tropical countries. Sayer drafted the paper. Margules commented on this draft and added some ideas.

Conflicts of Interest: The authors declare no conflict of interest.

\section{References}

1. Sloan, S.; Sayer, J.A. Forest resources assessment of 2015 shows positive global trends but forest loss and degradation persist in poor tropical countries. For. Ecol. Manag. 2015, 352, 134-145. [CrossRef]

2. Keenan, R.J.; Reams, G.A.; Achard, F.; de Freitas, J.V.; Grainger, A.; Lindquist, E. Dynamics of global forest area: Results from the FAO global forest resources assessment 2015. For. Ecol. Manag. 2015, 352, 9-20. [CrossRef]

3. Supriatna, J.; Mariati, S. Degradation of primate habitat at Tesso Nilo Forest with special emphasis on the Riau pale-thighed surili (Presbytis siamensis cana). J. Environ. Prot. 2014, 5, 1145-1152. [CrossRef]

4. Morales-Hidalgo, D.; Oswalt, S.N.; Somanathan, E. Status and trends in global primary forest, protected areas, and areas designated for conservation of biodiversity from the global forest resources assessment 2015. For. Ecol. Manag. 2015, 352, 68-77. [CrossRef]

5. Biodiversity in Locally Managed Lands. Available online: http://www.mdpi.com/journal/land/special_ issues/biodiversity_managed (accessed on 11 January 2017).

6. Sayer, J. The Peoples' Forest Balancing Local and Global Values; Universidad Autónoma de Madrid: Madrid, Spain, 2007.

7. Agrawal, A.; Chhatre, A.; Hardin, R. Changing governance of the world's forests. Science 2008, 320, 1460-1462. [CrossRef] [PubMed]

8. Whakatane Mechanism. Available online: http://whakatane-mechanism.org (accessed on 26 October 2016).

9. Cernea, M.M.; Schmidt-Soltau, K. The end of forcible displacements? Conservation must not impoverish people. Section I: The complexities of governing protected areas. In IUCN Commission on Environmental, Economic and Social Policy; IUCN: Gland, Switzerland, 2003; pp. 6-101.

10. Cernea, M.M.; Schmidt-Soltau, K. Poverty risks and national parks: Policy issues in conservation and resettlement. World Dev. 2006, 34, 1808-1830. [CrossRef]

11. Sheil, D.; Puri, R.; Wan, M.; Basuki, I.; Heist, M.V.; Liswanti, N.; Rachmatika, I.; Samsoedin, I. Recognizing local people's priorities for tropical forest biodiversity. J. Hum. Environ. 2006, 35, 17-24. [CrossRef]

12. Colchester, M. Forest Peoples, Customary Use and State Forests: The Case for Reform; Forest People's Programme: Oxford, UK, 2009.

13. White, A.; Martin, A. Who Owns the World's Forests; Forest Trends: Washington, DC, USA, 2002.

14. Harrison, R.P. Forests: The Shadow of Civilization; University of Chicago Press: Chicago, IL, USA, 2009.

15. Scott, J.C. Seeing Like a State: How Certain Schemes to Improve the Human Condition Have Failed; Yale University Press: London, UK, 1998.

16. Sayer, J.; Elliott, C.; Barrow, E.; Gretzinger, S.; Maginnis, S.; McShane, T.; Shepherd, G.; Colfer, C.; Capistrano, D. Implications for biodiversity conservation of decentralized forest resources management. In Politics of Decentralization, Forests, People and Power; Earthscan Publications: London, UK, 2005; pp. 121-137.

17. Forest People Praagramme. Available online: http://www.forestpeoples.org (accessed on 28 October 2016).

18. Frechette, A.; Reytar, K.; Saini, S.; Walker, W. Toward a Global Baseline of Carbon Storage in Collective Lands: An Updated Analysis of Indigenous Peoples' and Local Communities Contributions to Climate Change Mitigation; Rights \& Resources Institute: Washington, DC, USA, 2016.

19. Ribot, J.C.; Agrawal, A.; Larson, A.M. Recentralizing while decentralizing: How national governments reappropriate forest resources. World Dev. 2006, 34, 1864-1886. [CrossRef]

20. Agrawal, A.; Gibson, C.C. Enchantment and disenchantment: The role of community in natural resource conservation. World Dev. 1999, 27, 629-649. [CrossRef] 
21. Kellert, S.R.; Mehta, J.N.; Ebbin, S.A.; Lichtenfeld, L.L. Community natural resource management: Promise, rhetoric, and reality. Soc. Nat. Resour. 2000, 13, 705-715.

22. Sarin, M. Joint forest management in India: Achievements and unaddressed challenges. Unasylva 1995, 46, 30-36.

23. Sarin, M.; Ray, L. Who Is Gaining? Who Is Losing? Gender and Equity Concerns in Joint Forest Management; Society for Promotion of Wastelands Development: New Delhi, India, 1998.

24. Larson, A.M.; Barry, D.; Dahal, G.R. New rights for forest-based communities? Understanding processes of forest tenure reform. Int. For. Rev. 2010, 12, 78-96. [CrossRef]

25. Otto, J.; Zerner, C.; Robinson, J.; Donovan, R.; Lavelle, M.; Villarreal, R.; Salafsky, N.; Alcorn, J.; Seymour, F.; Kleyneyer, C. Natural Connections: Perspectives in Community-Based Conservation; Island Press: Washington, DC, USA, 2013.

26. Gilmour, D. Forty Years of Community-Based Forestry: A Review of Its Extent and Effectiveness; FAO: Rome, Italy, 2016.

27. De Blas, D.E.; Ruiz-Pérez, M.; Vermeulen, C. Management conflicts in cameroonian community forests. Ecol. Soc. 2011, 16, 8. [CrossRef]

28. Robinson, B.E.; Holland, M.B.; Naughton-Treves, L. Does secure land tenure save forests? A meta-analysis of the relationship between land tenure and tropical deforestation. Glob. Environ. Chang. 2014, 29, 281-293. [CrossRef]

29. Larson, A.M. Forest tenure reform in the age of climate change: Lessons for REDD+. Glob. Environ. Chang. 2011, 21, 540-549. [CrossRef]

30. Brosius, J.P.; Tsing, A.L.; Zerner, C. Representing communities: Histories and politics of community-based natural resource management. Soc. Nat. Resour. 1998, 11, 157-168. [CrossRef]

31. Acharya, K.P. Does community forests management supports biodiversity conservation? Evidences from two community forests from the mid hills of Nepal. J. For. Livelihood 2004, 4, 44-54.

32. Shrestha, U.B.; Shrestha, B.B.; Shrestha, S. Biodiversity conservation in community forests of Nepal: Rhetoric and reality. Int. J. Biodivers. Conserv. 2010, 2, 98-104.

33. Sayer, J.; Campbell, B. The Science of Sustainable Development: Local Livelihoods and the Global Environment; Cambridge University Press: Cambridge, UK, 2005.

34. Dudley, N.; Phillips, A.; Amend, T.; Brown, J.; Stolton, S. Evidence for biodiversity conservation in protected landscapes. Land 2016, 5, 38. [CrossRef]

35. Van Vliet, N.; Milner-Guilland, E.; Bousquet, F.; Saqalli, M.; Nasi, R. Effect of small-scale heterogeneity of prey and hunter distributions on the sustainability of bushmeat hunting. Conserv. Biol. 2010, 24, 1327-1337. [CrossRef] [PubMed]

36. Terborgh, J. Requiem for Nature; Island Press: Washington, DC, USA, 2004.

37. Terborgh, J.; Nuñez-Iturri, G.; Pitman, N.C.; Valverde, F.H.C.; Alvarez, P.; Swamy, V.; Pringle, E.G.; Paine, C. Tree recruitment in an empty forest. Ecology 2008, 89, 1757-1768. [CrossRef] [PubMed]

38. Sayer, J.; Margules, C.; Bohnet, I.; Boedhihartono, A.; Pierce, R.; Dale, A.; Andrews, K. The role of citizen science in landscape and seascape approaches to integrating conservation and development. Land 2015, 4, 1200-1212. [CrossRef]

39. Galbraith, M.; Bollard-Breen, B.; Towns, D. The community-conservation conundrum: Is citizen science the answer? Land 2016, 5, 37. [CrossRef]

40. Hodge, I.; Adams, W. Short-term projects versus adaptive governance: Conflicting demands in the management of ecological restoration. Land 2016. [CrossRef]

41. Sayer, J.; Sunderland, T.; Ghazoul, J.; Pfund, J.-L.; Sheil, D.; Meijaard, E.; Venter, M.; Boedhihartono, A.K.; Day, M.; Garcia, C. Ten principles for a landscape approach to reconciling agriculture, conservation, and other competing land uses. Proc. Natl. Acad. Sci. USA 2013, 110, 8349-8356. [CrossRef] [PubMed]

42. Sayer, J.A.; Margules, C.; Boedhihartono, A.K.; Sunderland, T.; Langston, J.D.; Reed, J.; Riggs, R.; Buck, L.E.; Campbell, B.M.; Kusters, K. Measuring the effectiveness of landscape approaches to conservation and development. Sustain. Sci. 2016. [CrossRef]

43. Wilshusen, P.R.; Brechin, S.R.; Fortwangler, C.L.; West, P.C. Reinventing a square wheel: Critique of a resurgent "protection paradigm" in international biodiversity conservation. Soc. Nat. Resour. 2002, 15, 17-40. [CrossRef]

44. Kumar, C. Whither 'community-based' conservation? Econ. Political Wkly. 2006, 41, 5313-5320. 
45. Pagdee, A.; Kim, Y.-S.; Daugherty, P.J. What makes community forest management successful: A meta-study from community forests throughout the world. Soc. Nat. Resour. 2006, 19, 33-52. [CrossRef]

46. Wunder, S.; Campbell, B.; Frost, P.G.H.; Sayer, J.A.; Iwan, R.; Wollenberg, L. When donors get cold feet: The community conservation concession in setulang (Kalimantan, Indonesia) that never happened. Ecol. Soc. 2008, 13, 12. [CrossRef]

47. Popova, U. Conservation, traditional knowledge, and indigenous peoples. Am. Behav. Sci. 2014, 58, $197-214$. [CrossRef]

48. Ostrom, E. A general framework for analyzing sustainability of social-ecological systems. Science 2009, 325, 419-422. [CrossRef] [PubMed]

49. Ostrom, E.; Janssen, M.A.; Anderies, J.M. Going beyond panaceas. Proc. Natl. Acad. Sci. USA 2007, 104, 15176-15178. [CrossRef] [PubMed]

50. Thackway, R.; Freudenberger, D. Accounting for the drivers that degrade and restore landscape functions in Australia. Land 2016, 5, 40. [CrossRef]

51. Langston, J.; Riggs, R.; Sururi, Y.; Sunderland, T. Estate crops more attractive than community forests in west Kalimantan, Indonesia. Land 2016, submitted.

(C) 2017 by the authors; licensee MDPI, Basel, Switzerland. This article is an open access article distributed under the terms and conditions of the Creative Commons Attribution (CC-BY) license (http://creativecommons.org/licenses/by/4.0/). 